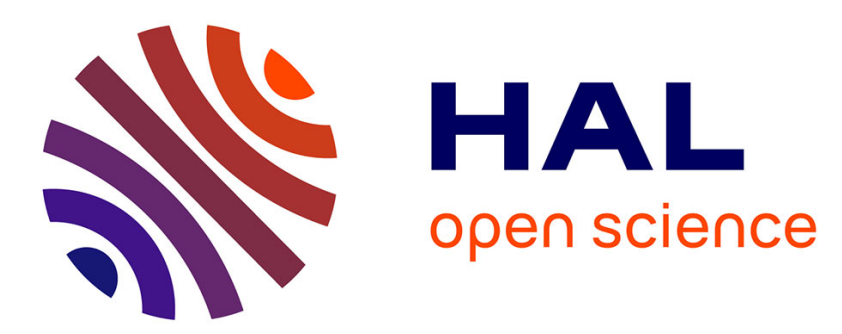

\title{
How to build reach-averaged rating curves for remote sensing discharge estimation? The potential of periodic geometry hypotheses
}

Mounir Mahdade, Nicolas Le Moine, Pierre Ribstein

\section{- To cite this version:}

Mounir Mahdade, Nicolas Le Moine, Pierre Ribstein. How to build reach-averaged rating curves for remote sensing discharge estimation? The potential of periodic geometry hypotheses. EGU General Assembly 2021, Apr 2021, online, France. 10.5194/egusphere-egu21-12476 . hal-03213246

\section{HAL Id: hal-03213246 \\ https://hal.sorbonne-universite.fr/hal-03213246}

Submitted on 30 Apr 2021

HAL is a multi-disciplinary open access archive for the deposit and dissemination of scientific research documents, whether they are published or not. The documents may come from teaching and research institutions in France or abroad, or from public or private research centers.
L'archive ouverte pluridisciplinaire HAL, est destinée au dépôt et à la diffusion de documents scientifiques de niveau recherche, publiés ou non, émanant des établissements d'enseignement et de recherche français ou étrangers, des laboratoires publics ou privés. 
EGU21-12476

https://doi.org/10.5194/egusphere-egu21-12476

EGU General Assembly 2021

(c) Author(s) 2021. This work is distributed under

the Creative Commons Attribution 4.0 License.

\section{How to build reach-averaged rating curves for remote sensing discharge estimation? The potential of periodic geometry hypotheses}

Mounir Mahdade, Nicolas Le Moine, and Pierre Ribstein

Sorbonne University, METIS UMR 7619, France (mounir.mahdade@upmc.fr)

River discharge is an essential component in the hydrological cycle. It is used to monitor rivers, the atmosphere, and the ocean through in-situ measurements, acquired on the surface, or from remote sensing to characterize natural disasters such as floods.

Estimating discharge in ungauged rivers with remote sensing data such as the Surface Water and Ocean Topography (SWOT) mission but without any prior in-situ information is difficult to solve, especially in the case of unknown bathymetry, friction, and lateral river flows. However, the current literature suggests that a better knowledge of bathymetry could considerably facilitate roughness and discharge inferring. SWOT observes water surface elevations, slopes, river widths for several overpasses. We propose an inverse method to estimate discharge in a non-uniform steady-state, maintaining longitudinal (alternating pool-riffle) and lateral (meanders) morphological variability of the river. The idea is to build a rating curve (water level - discharge relationship) at the reach scale using hydraulic signatures (quantities not related to a particular section of the reach, which characterize an aspect of the overall hydraulic behavior: e.g., flooded area as a function of $\mathrm{Q}$, mean water level as a function of $\mathrm{Q}$ ). The inverse approach requires building a model that produces rating curves that optimally correspond to the hydraulic signatures. It requires a direct hydraulic model and a geometric simplification to facilitate the resolution of the inverse problem.

The approach is based on the geomorphology of rivers. Indeed, the geometry of natural rivers presents high-frequency variability, characterized by alternating flow units: fast-flowing flow units in rectilinear and shallow areas (riffles), slow-flowing flow units in deeper areas (pools at alternating banks or inner side of meandering bends). This variability generates a variability of the hydraulic variables that covary at the reach scale. However, a simplification into a uniform geometry without spatial variability reappears as a bias in the frictional parameters, thus reducing the inversion's accuracy. For this, we propose a periodic approach that consists of representing the reach equivalent geometry by sinusoidal functions.

This direct periodic model is used to create a whole periodic geometry (curved based asymmetry sections, Kinoshita curves to model the meander planform) and then solve the Saint-Venant equations in the 2D Basilisk hydraulic model (http://basilisk.fr), which is based on finite volume 
methods with adaptive grid refinement.

This model does not require boundary conditions (use of periodic boundary conditions) and provides the ability to model floodplains and thus flood mapping. In the end, there are few parameters to adjust in the model (use of parameters covariances). 